\title{
Abbreviations of \\ Frequently Cited Sources
}

A Manuscripts at Amherst College will be indicated by this initial and the library catalogue number. The Amherst College numbering system usually designates leaves of a given manuscript, beyond the first, by the main number followed by $a, b$, $c$, etc., and references to specific leaves will reflect this system (e.g., of $L_{23} 3$ the first leaf is numbered 828, the second $828 \mathrm{a}$, etc.). Occasionally, however, the verso of a leaf will be lettered (e.g., Prose Fragment 19 is A 743 and 743a). In all cases I have followed the actual numbering, indicating the verso of a leaf by superscript $v$.

AB Bingham, Millicent Todd. Ancestors' Brocades: The Literary Debut of Emily Dickinson. New York: Harper \& Brothers, 1945 .

“Annals" Dickinson, Susan. "Annals of the Evergreens." Box 9. Dickinson Papers. Houghton Library, Harvard University, Cambridge, Mass.

Editing Franklin, R. W. The Editing of Emily Dickinson: $A$ Reconsideration. Madison: University of Wisconsin Press, 1967.

F

Franklin, R. W., ed. The Manuscript Books of Emily Dickinson. Cambridge: Harvard University Press, Belknap Press, 198I. References to this edition will use this initial and cite fascicle number only.

FF Bianchi, Martha Dickinson. Emily Dickinson Face to Face: Unpublished Letters with Notes and Reminiscences. Boston: Houghton Mifflin, 1932.

"Fascicles" Franklin, R. W. "The Emily Dickinson Fascicles." Studies in Bibliography 36 (1983): 1-20.

$\mathrm{H}$ Manuscripts at the Houghton Library, Harvard University, will be indicated by this initial and the library catalogue letter and/or number. 
Home Bingham, Millicent Todd. Emily Dickinson's Home: Letters of Edward Dickinson and His Family. New York: Harper \& Brothers, 1955.

L Johnson, Thomas H., and Theodora Ward, eds. The Letters of Emily Dickinson. Cambridge: Harvard University Press, Belknap Press, 1958. References to this edition will use this initial and give the number assigned by Johnson.

LF Wylder, Edith. The Last Face: Emily Dickinson's Manuscripts. Albuquerque: University of New Mexico Press, 1971.

LL Bianchi, Martha Dickinson. The Life and Letters of Emily Dickinson. Boston: Houghton Mifflin, 1924.

Life Sewall, Richard. The Life of Emily Dickinson. New York: Farrar, Straus and Giroux, 1974.

ML Franklin, R. W., ed. The Master Letters of Emily Dickinson. Amherst, Mass: Amherst College Press, 1986.

P Johnson, Thomas H., ed. The Poems of Emily Dickinson. Cambridge: Harvard University Press, Belknap Press, 1955. References to this edition will use this initial and give the number assigned by Johnson.

PF This refers to the Prose Fragments printed in Letters, vol. III, pp. 911-929. Citations will use these initials and give the number assigned by Johnson.

Revelation Bingham, Millicent Todd. Emily Dickinson: A Revelation. New York: Harper \& Brothers Publishers, 1954.

Set This term is used to refer to the unbound fascicle sheets, which can be found in Manuscript Books vol. 2. Franklin used the term to distinguish these sheets of poems grouped but not sewn together from the poet's "completed books."

YH Leyda, Jay. The Years and Hours of Emily Dickinson. New Haven and London: Yale University Press, 1960. 